\author{
І. М. Подольський, Д. В. Литкін, С. Ю. Штриголь
}

\title{
Дослідження гострої та підгострої токсичності перспективного антидепресанту атристаміну на щурах
}

\author{
Національний фармацевтичний університет, м. Харків
}

Ключові слова: атристамін, 2-метил-3(феніламінометил)-1Н-хінолін-4-он, гостра токсичність, підгостра токсичність

Класифіковані в декілька груп за механізмами дії антидепресанти широко застосовуються для лікування депресивних розладів. Однак триває дискусія щодо дієвості цих препаратів, оскільки короткотермінові ефекти лікування зазвичай $є$ незначними, а довгостроковий баланс користі та шкоди - недостатньо вивченим [1]. Часто вирішальними факторами, які перешкоджають успішному лікуванню, стають побічні ефекти антидепресантів, особливо за тривалого застосування. Так, для трициклічних антидепресантів і циталопраму доведено здатність подовжувати інтервал QT [2], особливо в літніх пацієнтів, що значно підвищує ризик розвитку кардіоваскулярних ускладнень. Для багатьох селективних інгібіторів зворотного захоплення серотоніну (SSRIs) як в експериментах на тваринах, так і в клінічних дослідженнях доведено гонадотоксичні ефекти [3]. Отже, у процесі розробки та впровадження в медичну практику інноваційних препаратів антидепресивної дії особливу увагу, з огляду на тривалість курсів застосування в клініці, привертають параметри безпеки досліджуваних речовин.

Об’єктом цього дослідження є 2-метил3-(феніламінометил)-1Н-хінолін-4-он (рис. 1), який під лабораторною назвою «Атристамін» вивчається як перспективний антидепресант 3 оригінальним спектром додаткових нейротропних ефектів, зокрема, ноотропною дією [4-7].

У попередніх власних дослідженнях гостру токсичність атристаміну визна-

(C) Колектив авторів, 2020 чали на мишах за методом Прозоровського за одноразового внутрішньошлункового (в/ш) введення водної тонкодисперсної суспензії, стабілізованої Твіном-80 [4]. За результатами розрахунків $\mathrm{LD}_{50}$ склала $(6133 \pm 568)$ мг/кг, що дозволило віднести атристамін за класифікацією Hodge та Sterner [8] до V класу - практично нетоксичних речовин. Це стало підставою для поглибленого вивчення властивостей досліджуваної молекули в аспекті їі токсичності.

Хоча за параметрами гострої токсичності досліджувана речовина може не виявляти ознак виразної шкідливої дії, тривале введення, навіть у низьких дозах, потенційно здатне спричинити побічні ефекти внаслідок кумуляції, утворення токсичних метаболітів. Дослідження можливої небезпеки повторних введень речовини, що вивчається, проводиться на підставі первинної інформації, отриманої за одноразового введення. Оскільки рекомендованими тест-організмами для досліджень підгострої, субхронічної та хронічної токсичності $€$ щури, доцільно визначити показники гострої токсичності атристаміну саме на цьому виді тварин. Дослідження підгострої токсичності, у свою чергу, передбачає одержання даних щодо токсичної дії речовини внаслідок введення її протягом обмеженого часу та за того шляху<smiles>Cc1[nH]c2ccccc2c(=O)c1CNc1ccccc1</smiles>

Рис. 1. Структурна формула 2-летил-3(фенілалінолетил)-1Н-хінолін-4-ону (атристаліну) 
введення, що передбачаються за умов застосування в клініці [9].

Мета дослідження - визначення гострої та підгострої токсичності перспективного антидепресанту атристаміну на щурах.

Матеріали та методи. Хілічні сполуки та реактиви. Для дослідження гострої та підгострої токсичності тваринам уводили атристамін, синтезований на кафедрі медичної хімії Національного фармацевтичного університету за раніше описаними методиками [10]. Індивідуальність та чистота досліджуваної сполуки були підтверджені спектральними та хроматографічними методами.

У разі дослідження гострої токсичності для введення атристаміну застосовували водну тонкодисперсну суспензію, стабілізовану Твіном-80, максимально допустимої концентрації 75 мг/ мл $з$ урахуванням фізико-хімічних i технологічних властивостей досліджуваної сполуки. За дослідження підгострої токсичності концентрація сполуки в суспензії складала 100 мг/10 мл.

Гостра токсичність. Експеримент проведено на 30 білих аутбредних щурах-самцях масою 160-190 г за методом Прозоровського [11]. Визначення діапазону доз для щурів грунтувалось на перерахунку значення $\mathrm{LD}_{50}$ для мишей 3 урахуванням коефіцієнтів площі поверхні тіла [12]. Таким чином була визначена доза, що відповідала центральному пробіту й складала 3100 мг/кг. Щурам, випадковим чином розподіленим на 5 груп по 6 тварин, натщесерце в/ш уводили атристамін у дозах 1100, 2100, 3100, 4100 i 5100 мг/кг відповідно. У групах тварин, у яких загальний об'єм суспензії складав понад 5 мл, атристамін уводили фракційно протягом декількох годин [9]. За тваринами спостерігали протягом 14 діб і реєстрували виживаність, споживання їжі та води, клінічні прояви інтоксикації за загальним станом, змінами пози, шкіри, кольору слизових оболонок, наявністю специфічних симптомів (у першу чергу з боку ЦНС - судоми, сонливість, міоз тощо).

Підгостру токсичність вивчали на 28 білих аутбредних щурах обох статей віком 3-4 місяці масою на початку дослідження - 150-170 г. Для експерименту тварини випадковим чином були розподілені на 4 групи: I група інтактний контроль, самці ( $\mathrm{n}=7)$; II група - щури-самці, що одержували атристамін у дозі 100 мг/кг (n=7); III група - інтактний контроль, самки (n = 7); IV група - щури-самки, що одержували атристамін у дозі 100 мг/кг $(\mathrm{n}=7)$. Вибір дози (100 мг/кг) базувався на попередніх дослідженнях, де вона була визначена як умовноефективна [13].

Дослідження проводили за повторного в/ш введення водної тонкодисперсної суспензії атристаміну, стабілізованої Твіном-80, впродовж 28 днів. Тваринам груп інтактного контролю вводили відповідну кількість розчинника (вода очищена). Досліджувані тестзразки вводили щоденно натщесерце о 9.00-10.00.

Для визначення динаміки маси тіла щурів зважували на $1,7,14,21$ та 29 добу експерименту. Протягом усього дослідження спостерігали за виживаністю тварин, споживанням ними їжі та води, а також реєстрували можливі клінічні прояви токсичної дії за загальним станом, змінами положення тіла, станом шкіри та шерсті, кольором слизових оболонок, окремими специфічними симптомами (зміни забарвлення сечі та фекалій, діарея, міоз, сльозоточивість, сонливість, судоми тощо).

Враховуючи фармакодинамічні ефекти атристаміну, протягом експерименту визначали його вплив на показники функціонального стану ЦНС (тест відкритого поля [14]) та координацію рухів і м'язовий тонус тварин (ротародтест [15]) на 1, 14 та 29 добу.

Через 1 год після передостаннього (27) введення речовин досліджували стан міокарда тварин, записуючи електрокардіограму (ЕГК) у II стандартному відведенні за допомогою приладу EК1T-03M2 під тіопенталовим наркозом (50 мг/кг). Розраховували частоту серцевих скорочень (ЧСС, уд/хв), систолічний показник (CП, \%), тривалість інтервалів PQ, QT (с) та комплекcy QRS (c), амплітуду зубців R, P, T (MB) $[16,17]$. 
Одразу після останнього (28) введення тварин вміщували в індивідуальні метаболічні клітки [18] для визначення спонтанного добового діурезу. На 29 добу тварин зважували, досліджували в тесті відкритого поля та ротарод-тесті, після чого негайно виводили 3 досліду шляхом дислокації шийних хребців під інгаляційним наркозом 3 метою одержання біологічного матеріалу для клінічних і біохімічних досліджень.

Усіх тварин піддавали розтину, проводили зважування та макроскопічне обстеження внутрішніх органів (головного мозку, серця, нирок, печінки, селезінки, наднирників, шлунка, гонад відповідно до статі), а також визначали їхні масові коефіцієнти (МК), що обчислювали в перерахуванні на 100 г маси тіла тварини. Для мікроскопічного аналізу відбирали зразки сенсомоторної зони кори головного мозку, серця, печінки, нирок, наднирників, селезінки, шлунка, сім'яників/яєчників. Внутрішні органи фіксували в $10 \%$ розчині нейтрального формаліну, зневоднювали в спиртах зростаючої міцності, заливали в целоїдин-парафін. Мікротомні зрізи фарбували гематоксиліном та еозином [19] і досліджували стандартними методами світлової мікроскопії [20-23].

Визначали об'єм і колір сечі, прозорість, $\mathrm{pH}$, густину, вміст білка за реакцією 3 сульфосаліциловою кислотою, вміст глюкози глюкозооксидазним методом [24]. Вимірювали вміст креатиніну (за реакцією з пікриновою кислотою) [25] у крові та сечі, швидкість клубочкової фільтрації (ШКФ) розраховували за кліренсом ендогенного креатиніну. Клінічний аналіз крові проводили загальноприйнятими методами. Визначали гемоглобін, вміст еритроцитів, кольоровий показник (КП), вміст лейкоцитів і швидкість осідання еритроцитів (ШОЕ) [24].

У сироватці крові фотометрично за допомогою відповідних стандартних наборів реактивів виробництва ТОВ НВП «Філісіт-Діагностика» (Україна) визначали згідно 3 інструкціями до застосування: вміст сечовини - колориметричним методом ( СечовинаОФА» НР018.03), загальний білок - біуретовим методом («Загальний білок» НР010.01), вміст альбуміну - за реакцією з бромкрезоловим зеленим («Альбумін» НР002.01), вміст глюкози глюкозооксидазним методом («Глюкоза-Ф» НР009.02), активність аспартатамінотрансферази (АсAT) і аланінамінотрансферази (АлАТ) - кінетичними методами («АсAТ-КIH» НР004.02 i «АлАТ-КІН» НР001.02), вміст загального білірубіну - методом Йендрашика («Білірубін» НР005.01), загального холестерину - ферментативним методом («Холестерин-Ф» НР026.02).

Усі етапи дослідження виконано відповідно до директиви Ради ЄС 2010/63/ EU (від 22 вересня 2010 р.) про дотримання законів, постанов та адміністративних положень держав СС із питань захисту тварин, що використовуються з експериментальною та іншою науковою метою [26].

Статистичну обробку одержаних результатів здійснювали методами варіаційної статистики 3 використанням t-критерію Стьюдента та непараметричних методів аналізу (Mann-Whitney U Test) за допомогою комп'ютерної програми STATISTICA 10.0 [27].

Результати та їх обговорення. Гостpa токсичність. Згідно з одержаними результатами, у групі щурів, яким одноразово в/ш вводили атристамін у дозі $1100 \mathrm{мг/кг,} \mathrm{не} \mathrm{зареєстровано} \mathrm{жод-}$ них проявів токсичного впливу досліджуваної речовини. Тварини добре переносили введення, після чого їхній загальний стан, зовнішній вигляд i поведінка залишались незмінними протягом усього дня спостереження. Протягом 2-3 год після введення атристаміну в дозі 2100 мг/кг виявлено перші ознаки інтоксикації: помірну збудженість, пілоерекцію, тремтіння кінцівок. Інтенсивність цих проявів швидко зменшувалась, і до кінця дня спостереження стан тварин нормалізувався.

Під впливом атристаміну в дозах 3100 мг/кг, 4100 мг/кг і 5100 мг/кг картина інтоксикації після введення останньої порції суспензії була більш розгорнутою та мала чіткий дозозалежний характер. За 2-3 год підвищена збудливість, тремтіння кінцівок змінювались млявістю та загальною 
загальмованістю. Надалі до кінця дня спостереження всі тварини перебували в нерухомому або малорухомому стані, реакція на зовнішні подразники була дозозалежно зниженою, дихання прискорене. Втрати рефлексу перевертання в жодній групі тварин не було зареєстровано.

Згідно з одержаними даними виживаності в групах тварин протягом усього експерименту (табл. 1), критичною в аспекті летальності є перша доба після введення речовини. Тварини, що вижили в групах із зареєстрованою летальністю, при подальшому спостереженні повертались до нормального стану й вже на 4-5 добу не відрізнялись за загальним станом і поведінкою від щурів, що одержували нижчі дози.

Одержані результати виживаності тварин (табл. 1) дозволити розрахувати показник $\mathrm{LD}_{50}$ за в/ш введення щурам, який у разі застосування методу Бліса-Прозоровського [28] склав
(4164 \pm 309$)$ мг/кг. Також були розраховані дози $\mathrm{LD}_{16}$ i $\mathrm{LD}_{84}$, що дорівнюють відповідно 2472 мг/кг і 5856 мг/кг. Таким чином, за величиною $\mathrm{LD}_{50}$ для щурів атристамін може бути віднесений за класифікацією Hodge та Sterner [8] до IV класу - малотоксичних речовин.

Підгостра токсичність. За результатами вивчення підгострої токсичності атристаміну встановлено, що в/ш введення досліджуваної речовини в дозі 100 мг/кг протягом 28 днів не чинило негативного впливу на зовнішній вигляд, загальний стан і поведінку щурів, жодна 3 тварин не загинула. Динаміка маси тіла (рис. 2) не мала достовірних відмінностей від такої інтактних тварин відповідно до статі.

Враховуючи нейротропні властивості атристаміну, за вивчення підгострої токсичності особливу увагу привертав вплив досліджуваної сполуки на функціональний стан центральної нервової системи (ЦНС), координацію рухів і

Таблиця 1

Показники виживаності шурів за дослідження гострої токсичності атристаміну $(n=30)$

\begin{tabular}{|c|c|c|c|c|c|c|c|}
\hline \multirow{2}{*}{$\begin{array}{l}\text { Група } \\
\text { тварин }\end{array}$} & \multirow{2}{*}{$\begin{array}{c}\text { Доза атристаміну, } \\
\text { мг/кг }\end{array}$} & \multirow{2}{*}{$\begin{array}{c}\text { Кількість тварин } \\
\text { у групі }\end{array}$} & \multicolumn{5}{|c|}{$\begin{array}{c}\text { Кількість загиблих тварин } \\
\text { по днях спостереження }\end{array}$} \\
\hline & & & 1 & 4 & 7 & 10 & 14 \\
\hline 1 & 1100 & 6 & 0 & 0 & 0 & 0 & 0 \\
\hline 2 & 2100 & 6 & 0 & 0 & 0 & 0 & 0 \\
\hline 3 & 3100 & 6 & 2 & 2 & 2 & 2 & 2 \\
\hline 4 & 4100 & 6 & 3 & 3 & 3 & 3 & 3 \\
\hline 5 & 5100 & 6 & 4 & 4 & 4 & 4 & 4 \\
\hline
\end{tabular}

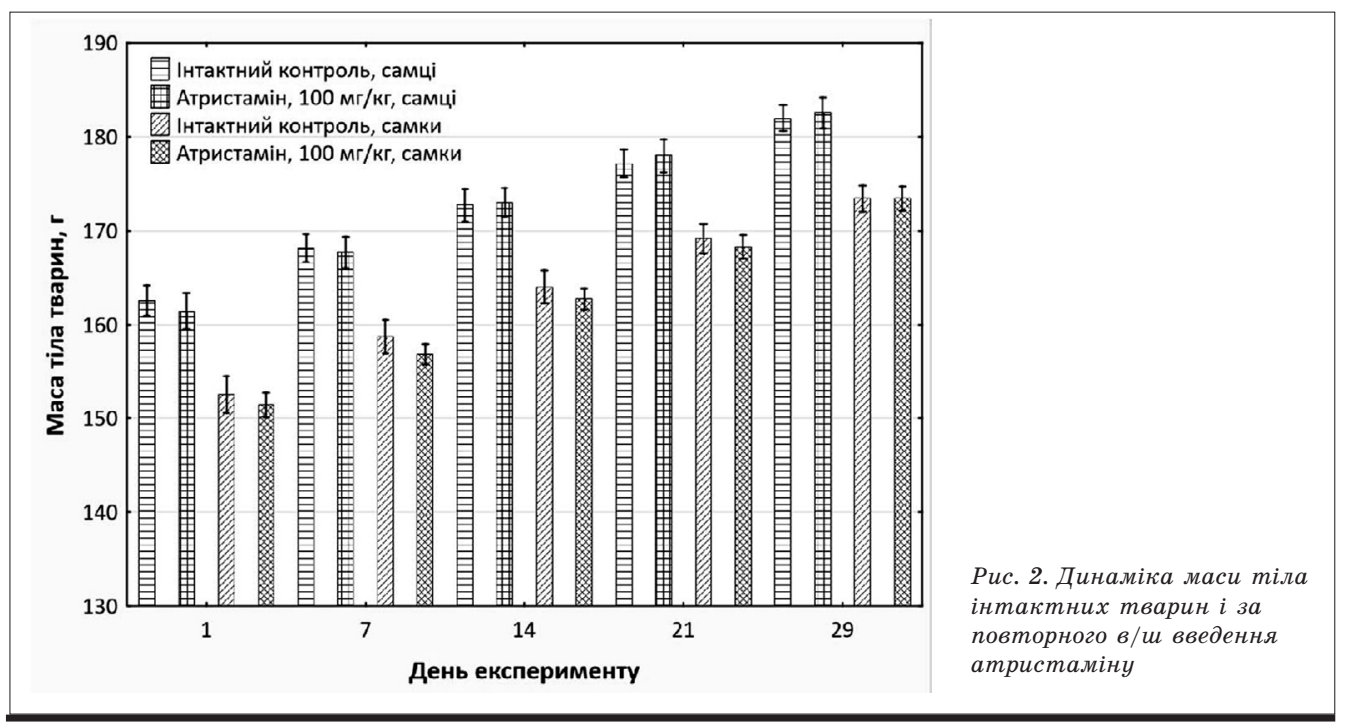


Показники функціонального стану центральної нервової систели щурів у тесті відкритого поля за впливу атристаліну, $Q_{50}\left(Q_{25}-Q_{75}\right), n=28$

\begin{tabular}{|c|c|c|c|c|c|}
\hline \multirow{3}{*}{ Показник } & \multirow{3}{*}{ Доба } & \multicolumn{4}{|c|}{ Група тварин } \\
\hline & & \multicolumn{2}{|c|}{ самці } & \multicolumn{2}{|c|}{ самки } \\
\hline & & $\begin{array}{l}\text { інтактний } \\
\text { контроль }\end{array}$ & $\begin{array}{c}\text { атристамін, } \\
100 \text { мг/кг }\end{array}$ & $\begin{array}{l}\text { інтактний } \\
\text { контроль }\end{array}$ & $\begin{array}{c}\text { атристамін, } \\
100 \text { мг/кг }\end{array}$ \\
\hline \multirow{3}{*}{$\begin{array}{l}\text { Пересічені } \\
\text { квадрати }\end{array}$} & 1 & $11(7-15)$ & $11(9-17)$ & $12(10-16)$ & $15(12-20)$ \\
\hline & 14 & $7(6-10)$ & $8(5-10)$ & $9(5-11)$ & $8(5-12)$ \\
\hline & 29 & $12(8-16)$ & $13(9-14)$ & $9(7-12)$ & $10(8-14)$ \\
\hline \multirow{3}{*}{$\begin{array}{l}\text { Вертикальні } \\
\text { стійки }\end{array}$} & 1 & $6(4-8)$ & $8(6-10)$ & $7(4-9)$ & $6(5-11)$ \\
\hline & 14 & $3(2-4)$ & $4(3-6)$ & $5(3-7)$ & $6(3-8)$ \\
\hline & 29 & $6(4-9)$ & $8(3-10)$ & $6(3-8)$ & $7(4-10)$ \\
\hline \multirow{3}{*}{$\begin{array}{l}\text { Обстежені } \\
\text { отвори }\end{array}$} & 1 & $6(4-8)$ & $8(7-10)$ & $0(7-12)$ & $9(5-13)$ \\
\hline & 14 & $6(4-7)$ & $5(3-7)$ & $6(3-8)$ & $6(2-6)$ \\
\hline & 29 & $8(4-11)$ & $9(7-12)$ & $7(4-10)$ & $8(5-11)$ \\
\hline \multirow{3}{*}{$\begin{array}{l}\text { Кількість актів } \\
\text { грумінгу }\end{array}$} & 1 & $2(0-3)$ & $2(1-3)$ & $2(2-4)$ & $3(2-5)$ \\
\hline & 14 & $1(0-1)$ & $1(0-1)$ & $1(0-2)$ & $1(0-2)$ \\
\hline & 29 & $1(0-1)$ & $0(0-1)$ & $1(0-1)$ & $1(0-1)$ \\
\hline \multirow{3}{*}{$\begin{array}{l}\text { Кількість } \\
\text { дефекацій }\end{array}$} & 1 & $1(1-2)$ & $2(0-2)$ & $2(1-3)$ & $1(0-3)$ \\
\hline & 14 & $1(0-1)$ & $1(1-2)$ & $1(0-1)$ & $1(0-1)$ \\
\hline & 29 & $1(0-1)$ & $1(0-1)$ & $0(0-1)$ & $1(0-1)$ \\
\hline \multirow{3}{*}{$\begin{array}{l}\text { Кількість } \\
\text { уринацій }\end{array}$} & 1 & $1(0-2)$ & $1(0-2)$ & $1(1-2)$ & $1(0-2)$ \\
\hline & 14 & $1(0-1)$ & $1(0-1)$ & $1(0-2)$ & $0(0-1)$ \\
\hline & 29 & $1(1-2)$ & $1(0-1)$ & $1(0-2)$ & $1(0-2)$ \\
\hline \multirow{3}{*}{$\begin{array}{l}\text { Сума усіх } \\
\text { активностей }\end{array}$} & 1 & $28(25-31)$ & 34 (26-39) & $35(30-41)$ & $40(28-48)$ \\
\hline & 14 & $18(15-20)$ & 19 (13-27) & 20 (13-29) & $26(12-27)$ \\
\hline & 29 & $29(19-38)$ & $31(20-38)$ & $23(16-32)$ & $26(20-36)$ \\
\hline
\end{tabular}

м'язовий тонус тварин. Як свідчать дані таблиці 2, атристамін за повторних уведень не чинить негативного впливу на локомоторну та орієнтовнодослідницьку активність, а також вегетативний супровід емоційних реакцій порівняно 3 синхронним контролем відповідно до статі.

Також не зареєстровано жодного негативного впливу атристаміну на координацію рухів і м’язовий тонус щурів, що підтверджує відсутність нейротоксичної дії атристаміну за тривалого введення (табл. 3).

Атристамін за тривалого введення не чинить негативного впливу на всі досліджені показники ЕКГ. У всіх групах тварин ритм синусовий. Відсутність змін СП свідчить про нормальну скоротливу здатність міокарда. Не спостеріга- ли притаманне низці антидепресантів [2] подовження інтервалу QT (предиктор тяжких порушень серцевого ритму), змін тривалості інтервалу PQ (маркер атріовентрикулярної провідності).

Результати аналізу сечі щурів, зібраної протягом доби після останнього введення атристаміну, підтверджують відсутність впливу тривалого застосування досліджуваної речовини на показники добового діурезу, питомої густини, $\mathrm{pH}$ сечі, вмісту білка порівняно 3 інтактним контролем. У сечі всіх експериментальних тварин глюкоза не виявлена. Відсутні значущі відмінності показників азотистого обміну (вміст сечовини та креатиніну в крові, концентрація креатиніну в сечі, ШКФ) порівняно 3 інтактним контролем. Вони знаходились у межах фізіологічної норми відповідно до статі. 
Координація рухів і м'язовий тонус шурів у тесті стрижня, шо обертається, під впливол атристаліну, $M \pm m, Q 50$ (Q25-Q75), $n=28$

\begin{tabular}{|c|c|c|c|c|c|}
\hline \multirow{3}{*}{ Показник } & \multirow{3}{*}{ Доба } & \multicolumn{4}{|c|}{ Група тварин } \\
\hline & & \multicolumn{2}{|c|}{ самці } & \multicolumn{2}{|c|}{ самки } \\
\hline & & $\begin{array}{l}\text { інтактний } \\
\text { контроль }\end{array}$ & $\begin{array}{c}\text { атристамін, } \\
100 \text { мг/кг }\end{array}$ & $\begin{array}{l}\text { інтактний } \\
\text { контроль }\end{array}$ & $\begin{array}{c}\text { атристамін, } \\
100 \text { мг/кг }\end{array}$ \\
\hline \multirow{3}{*}{$\begin{array}{l}\text { Час перебу- } \\
\text { вання на } \\
\text { стрижні, с }\end{array}$} & 1 & $\begin{array}{c}121,7 \pm 19,2 \\
124 \\
(96-180)\end{array}$ & $\begin{array}{c}117,9 \pm 21,0 \\
104 \\
(76-180)\end{array}$ & $\begin{array}{c}114,3 \pm 21,0 \\
123 \\
(62-166)\end{array}$ & $\begin{array}{c}115,4 \pm 20,8 \\
128 \\
(54-162)\end{array}$ \\
\hline & 14 & $\begin{array}{c}153,6 \pm 14,6 \\
164 \\
(135-180)\end{array}$ & $\begin{array}{c}148,4 \pm 17,2 \\
165 \\
(136-180)\end{array}$ & $\begin{array}{c}150,6 \pm 12,4 \\
152 \\
(122-180)\end{array}$ & $\begin{array}{c}141,6 \pm 18,4 \\
167 \\
(92-180)\end{array}$ \\
\hline & 29 & $\begin{array}{c}172,3 \pm 5,5 \\
180 \\
(164-180)\end{array}$ & $\begin{array}{c}165,7 \pm 12,4 \\
180 \\
(168-180)\end{array}$ & $\begin{array}{c}170,6 \pm 6,4 \\
180 \\
(156-180)\end{array}$ & $\begin{array}{c}171,4 \pm 5,6 \\
180 \\
(164-180)\end{array}$ \\
\hline
\end{tabular}

Комплекс цих даних вказує на відсутність в атристаміну нефротоксичних властивостей.

Повторне багаторазове введення атристаміну не мало статистично значущого впливу на такі біохімічні показники крові, як вміст глюкози, загального білка, альбуміну, холестерину, білірубіну та активності АлАТ і АсAТ. Усі вони в інтактних і дослідних групах не виходили за межі фізіологічних норм відповідно до статі та фази онтогенезу. Це свідчить, зокрема, про відсутність ознак гепатотоксичності досліджуваної сполуки.

Аналіз гематологічних показників тварин (гемоглобін, кількість еритроцитів та лейкоцитів, КП, ШОЕ) підтвердив відсутність негативного впливу на них багаторазового введення атристаміну.

Наступним етапом дослідження було вивчення впливу атристаміну за багаторазового введення на морфологічний стан внутрішніх органів самців і самок щурів.

Макроскопічний аналіз головного мозку, серця, печінки, нирок, наднирників, селезінки, шлунка та гонад показав, що органи тварин, яким уводили атристамін, не відрізняються за будовою, розмірами, консистенцією та кольором від відповідних органів інтактних тварин.

Розрахунки МК внутрішніх органів (табл. 4) доводять, що досліджувана

Таблиця 4

Масові коефіцієнти внутрішніх органів иурів за тривалого (28 діб) внутрішньошлункового введення атристаліну, $\mathrm{M} \pm \mathrm{m}$

\begin{tabular}{|c|c|c|c|c|}
\hline \multirow{3}{*}{ Орган } & \multicolumn{4}{|c|}{ Експериментальна група } \\
\hline & \multicolumn{2}{|c|}{$\begin{array}{c}\text { масовий коефіцієнт органів } \\
\text { у самців, г/100 г }\end{array}$} & \multicolumn{2}{|c|}{$\begin{array}{c}\text { масовий коефіцієнт органів } \\
\text { у самок, г/100 г }\end{array}$} \\
\hline & $\begin{array}{c}\text { інтактний } \\
\text { контроль } \\
(\mathbf{n}=7)\end{array}$ & $\begin{array}{c}\text { атристамін, } \\
100 \text { мг/кг } \\
(n=7)\end{array}$ & $\begin{array}{c}\text { інтактний } \\
\text { контроль } \\
(\mathbf{n}=7)\end{array}$ & $\begin{array}{c}\text { атристамін, } \\
100 \text { мг/кг } \\
(n=7)\end{array}$ \\
\hline Головний мозок & $1,036 \pm 0,036$ & $1,069 \pm 0,035$ & $0,981 \pm 0,031$ & $0,992 \pm 0,030$ \\
\hline Печінка & $4,325 \pm 0,116$ & $4,405 \pm 0,081$ & $4,249 \pm 0,112$ & $4,351 \pm 0,108$ \\
\hline Серце & $0,470 \pm 0,018$ & $0,487 \pm 0,019$ & $0,435 \pm 0,019$ & $0,453 \pm 0,024$ \\
\hline Нирки & $0,667 \pm 0,020$ & $0,670 \pm 0,013$ & $0,643 \pm 0,021$ & $0,648 \pm 0,020$ \\
\hline Наднирники & $0,042 \pm 0,001$ & $0,043 \pm 0,001$ & $0,044 \pm 0,002$ & $0,046 \pm 0,002$ \\
\hline Селезінка & $0,420 \pm 0,019$ & $0,428 \pm 0,017$ & $0,429 \pm 0,020$ & $0,440 \pm 0,020$ \\
\hline Сім'яники & $1,132 \pm 0,029$ & $1,198 \pm 0,030$ & - & - \\
\hline Яєчники & - & - & $0,062 \pm 0,005$ & $0,064 \pm 0,005$ \\
\hline
\end{tabular}


речовина за повторних уведень не спричиняє змін цих показників порівняно з інтактним контролем і відхилень від фізіологічних норм відповідно до статі.

За повторних в/ш уведень упродовж 28 діб атристамін не спричиняв будьяких специфічних змін гістоструктури сенсомоторної кори головного мозку, серця, печінки, нирок, селезінки, наднирників, шлунка та гонад. Гістологічна картина органів цих тварин була подібна та не мала суттєвих відмінностей від такої в щурів груп інтактного контролю. Ознак запальних, дистрофічних або гіпертрофічних реакцій не виявлено.

Таким чином, результати вивчення підгострої токсичності атристаміну показали, що щоденне в/ш уведення упродовж 28 діб досліджуваної сполуки в дозі 100 мг/кг щурам не чинить токсичної дії незалежно від статі тварин за критеріями відсутності впливу на їх загальний фізичний стан, динаміку маси тіла, поведінку, показники функціонального стану ЦНС, серця, нирок, печінки, клінічних аналізів крові та сечі, біохімічні маркери сироватки крові, масові коефіцієнти внутрішніх органів, їхній макроскопічний стан i гістоструктуру.

\section{Висновки}

За результатами вивчення гострої токсичності перспективного антидепресанту атристаміну розраховано показник $\mathrm{LD}_{50}$ за одноразового внутрішньошлункового введення щурам, який складає (4164 \pm 309$)$ мг/кг, що дозволяє віднести досліджувану сполуку за класифікацією Hodge та Sterner до IV класу (малотоксичних) речовин.

Щоденне внутрішньошлункове введення атристаміну впродовж 28 діб щурам у дозі 100 мг/кг не викликало достовірних відмінностей динаміки маси тіла, показників функціонального стану ЦНС, серця, сечовидільної та гепатобіліарної систем, загальних аналізів крові та сечі.

Багаторазове введення атристаміну не впливало на масові коефіцієнти внутрішніх органів, не змінювало їхній макроскопічний стан і гістоструктуру.

Результати дослідження гострої та підгострої токсичності атристаміну на щурах дозволяють зробити висновок про низьку токсичність досліджуваної речовини та безпечність за її тривалого (28 діб) внутрішньошлункового введення в умовнотерапевтичній дозі.

1. Cipriani A., Furukawa T. A., Salantietal G. Comparative efficacy and acceptability of 21 antidepressant drugs for the acute treatment of adults with major depressive disorder: a systematic review and network meta-analysis. Lancet. 2018. № 391. P. 1357-1366.

2. Evaluating the risk of QTc prolongation associated with antidepressant use in older adults: a review of the evidence. M. P. Rochester, A. M. Kane, S. A. Linnebur, D. R. Fixen. Therapeutic Advances in Drug Safety. 2018. V. 9 (6). P. 297-308.

3. Beeder L. A., Samplaski M. K. Effect of antidepressant medications on semen parameters and male fertility. International Journal of Urology. 2019. Available on-line. URL: https://onlinelibrary.wiley. com/doi/epdf/10.1111/iju.14111.

4. 2-Метил-3-фениламинометилхинолин-4-он - потенциальный антидепрессант с ноотропными свойствами. С. Ю. Штрыголь, В.А. Зубков, И. Н. Подольский, И. С. Гриценко. Экспериментальная и клиническая фармакология. 2012. Т. 75, № 4. С. 7-9.

5. Podolsky I. M., Shtrygol S. Yu. Neuroprotective activity of 2-methyl-3-phenylamino-methylquinolin4-one in experimental traumatic brain injury in rats. Journal of Chemical and Pharmaceutical Research. 2015. V. 7 (4). P. 518-524.

6. Podolsky I., Shtrygol S. The analgesic properties of a promising antidepressant - 2-methyl-3(phenylaminomethyl)-1H-quinolin-4-one. The Pharma Innovation Journal. 2017. V. 6, № 8. P. 156-160.

7. Podolsky I., Shtrygol S. The memory and learning enhancing effects of Atristamine. Pharmacia. 2019. V. 66, Issue 1. P. 13-18.

8. Hodge H. C., Sterner J. H. Combined tabulation of toxicity classes. From «Handbook of toxicology», V. 1; ed: W. S. Spector. Philadelphia : W. B. Saunders Company, 1956. P. 689-690.

9. Доклинические исследования лекарственных средств: метод. рекоменд.; под ред. А. В. Стефанова. Киев : Авиценна, 2002. 528 с.

10. 3-Диметиламинометил-2-метил-1Н-хинолин-4-он - эффективный реагент в синтезе 3-аминометилзамещенных хинолонов. В. А. Зубков, И. С. Гриценко, С. Г. Таран, И. Н. Подольский и др. Журнал органічної та фармацевтичної хімії. 2005. Т. 3, № 2 (10). С. 23-27. 
11. Прозоровский В. Б. Табличный экспресс-метод определения средних эффективных мер воздействия на биологические объекты. Токсикологический вестник. 1998. № 1. С. 28-32.

12. Nair A. B. Jacob S. A simple practice guide for dose conversion between animals and human. Journal of Basic and Clinical Pharmacy. 2016. № 7. P. 27-31.

13. Подольський I. М., Штриголь С. Ю. Дозозалежність ефектів перспективного антидепресанта 3 ноотропними властивостями 2-метил-3-(феніламінометил)-1Н-хінолін-4-ону. Клінічна фармація. 2016. Т. 20, № 4. С. 46-51.

14. Drug Discovery and Evaluation: Pharmacological Assays; H. G. Vogel (ed.). $3^{\text {rd }}$ edition. Springer, Berlin, Heidelberg, New York, 2008. 2068 p.

15. The Behavioral Assessment of Sensorimotor Processes in the Mouse: Acoustic Startle, Sensory Gating, Locomotor Activity, Rotarod, and Beam Walking. P. Curzon, M. Zhang, R. J. Radek et al. In: Buccafusco JJ, editor. Methods of Behavior Analysis in Neuroscience. $2^{\text {nd }}$ edition. Boca Raton (FL): CRC Press / Taylor \& Francis; 2009. Chapter 8. URL: https://www.ncbi.nlm.nih.gov/books/NBK5236.

16. Лабораторные животные. Разведение, содержание, использование в эксперименте. И. П. Западнюк, В. И. Западнюк, Е. А. Захария, Б. В. Западнюк. Киев : Вища шк., 1983. 383 с.

17. Джанашия П. Х., Шевченко Н. М., Маленьков В. К. Руководство по интерпретации ЭКГ (тесты по интерпретации ЭКГ). Москва : Оверлей, 2003. 273 с.

18. Оптимизация условий исследования функций почек в хроническом эксперименте. Э. Ф. Баринов, А. Г. Кот, Е. Д. Якубенко, Л. А. Буряк. Физиологический журнал. 1987. Т. 33, № 6. С. 80-82.

19. Меркулов Г. А. Курс патологогистологической техники. Москва : Медицина, Ленингр. отд-ние, 1969. $424 \mathrm{c}$

20. Гистология, цитология и эмбриология; под ред. Ю. И. Афанасьева, Н. А. Юриной. 5-е изд., перераб. и доп. Москва : Медицина, 2002. 744 с.

21. Гистология: учебник; под ред. Э. Г. Улумбекова, Ю. А. Челышева. 2-е изд., перераб. и доп. Москва : ГЭОТАР-МЕД, 2002. 672 с.

22. Микроскопическая техника: руководство; под ред. Д. С. Саркисова, Ю. Л. Перова. Москва : Медицина, 1996. 544 с.

23. Хэм А., Кормак Д. Гистология; пер. с англ. Т. 5. Москва : Мир, 1983. 294 с.

24. Клиническая лабораторная диагностика: методы исследования. И. А. Зупанец, С. В. Мисюрева, В. В. Прописнова и др.; под ред. И. А. Зупанца. 3-е изд., перераб. и доп. Харьков : Изд-во НФаУ; Золотые страницы, 2005. 200 с.

25. Клиническая лабораторная диагностика: нац. руководство: в 2 т.; под ред. В. В. Долгова, В. В. Меньшикова. Москва : ГЭОТАР-Медиа, 2012. 928 с.

26. Council Directive 2010/63/EU of 22 September 2010 on the protection of animals used for scientific purposes .Official Journal of the European Communities. 2010. L 276. P. 33-79.

27. Реброва О. Ю. Статистический анализ медицинских данных. Применение пакета прикладных программ STATISTICA. 3-е изд. Москва :Медиа Сфера, 2006. 312 с.

28. Прозоровский В. Б. Статистическая обработка результатов фармакологических исследований. Психофармакол. биол. наркол. 2007. Т. 7, № 3-4. С. 2090-2120.

\section{І. М. Подольський, Д. В. Литкін, С. Ю. Штриголь Дослідження гострої та підгострої токсичності перспективного антидепресанту атристаміну на щурах}

Вирішальними факторами, які перешкоджають успішному лікуванню депресивних розладів, часто стають побічні ефекти антидепресантів, особливо за тривалого застосування. У процесі розробки та впровадження в медичну практику інноваційних лікарських засобів антидепресивної дії особливу увагу, з огляду на тривалість курсів застосування в клініці, необхідно звертати на параметри безпеки досліджуваних речовин.

Мета дослідження - вивчення гострої та підгострої токсичності перспективного антидепресанту з оригінальним спектром додаткових нейротропних ефектів 2-метил-3-(феніламінометил)-1Нхінолін-4-ону (атристаміну) на щурах.

Параметри гострої токсичності атристаміну за одноразового внутрішньошлункового введення досліджували на білих аутбредних щурах-самцях за методом Прозоровського. Вивчення підгострої токсичності проводили на білих нелінійних щурах обох статей віком 3-4 місяці за повторного внутрішньошлункового введення атристаміну впродовж 28 днів в умовно терапевтичній дозі 100 мг/кг. Протягом експерименту визначали вплив тривалого введення атристаміну на динаміку маси тіла тварин, показники функціонального стану ЦНС, серця, сечовидільної та гепатобіліарної систем, загальні аналізи крові та сечі, масові коефіцієнти внутрішніх органів, їхній макроскопічний стан і гістоструктуру.

За результатами вивчення гострої токсичності атристаміну розраховано показник $\mathrm{LD}_{50}$ за одноразового внутрішньошлункового введення щурам, який складає (4164 \pm 309$)$ мг/кг, що дозволяє віднести досліджувану сполуку за класифікацією Hodge та Sterner до IV класу (малотоксичних) речовин. 
Результати дослідження підгострої токсичності свідчать, що щоденне внутрішньошлункове введення атристаміну в умовно терапевтичній дозі впродовж 28 діб щурам не викликало достовірних відмінностей динаміки маси тіла, показників функціонального стану ЦНС, серця, сечовидільної та гепатобіліарної систем, загальних аналізів крові та сечі. Також показано, що багаторазове введення атристаміну не впливало на масові коефіцієнти внутрішніх органів, не змінювало їхній макроскопічний стан і гістоструктуру.

Таким чином, результати дослідження гострої та підгострої токсичності атристаміну на щурах дозволяють зробити висновок про низьку токсичність досліджуваної речовини та безпечність за їі тривалого (28 діб) внутрішньошлункового введення в умовно терапевтичній дозі.

Ключові слова: атристамін, 2-метил-3-(феніламінометил)-1Н-хінолін-4-он, гостра токсичність, підгостра токсичність

\section{И. Н. Подольский, Д. В. Лыткин, С. Ю. Штрыголь \\ Исследование острой и подострой токсичности перспективного антидепрессанта атристамина на крысах}

Решающими факторами, которые препятствуют успешному лечению депрессивных расстройств, часто становятся побочные эффекты антидепрессантов, особенно при длительном применении. В процессе разработки и внедрения в медицинскую практику инновационных лекарственных средств антидепрессивного действия особое внимание, учитывая продолжительность курсов применения в клинике, необходимо обращать на параметры безопасности исследуемых веществ.

Цель исследования - изучение острой и подострой токсичности перспективного антидепрессанта с оригинальным спектром дополнительных нейротропных эффектов 2-метил-3-(фениламинометил)-1Н-хинолин-4-она (атристамина) на крысах.

Параметры острой токсичности атристамина при однократном внутрижелудочном введении исследовали на белых аутбредных крысах-самцах по методу Прозоровского. Изучение подострой токсичности проводили на белых нелинейных крысах обоих полов в возрасте 3-4 месяца при повторном внутрижелудочном введении атристамина в течение 28 суток в условно терапевтической дозе 100 мг/кг. В ходе эксперимента определяли влияние длительного введения атристамина на динамику массы тела животных, показатели функционального состояния ЦНС, сердца, мочевыделительной и гепатобилиарной систем, общие анализы крови и мочи, массовые коэффициенты внутренних органов, их макроскопическое состояние и гистоструктуру.

По результатам изучения острой токсичности атристамина рассчитан показатель $\mathrm{LD}_{50}$ при однократном внутрижелудочном введении крысам, который составляет (4164 \pm 309$)$ мг/кг, что позволяет отнести исследуемое соединение по классификации Hodge и Sterner к IV классу (малотоксичных) веществ.

Результаты исследования подострой токсичности свидетельствуют, что ежедневное внутрижелудочное введение атристамина в условно терапевтической дозе в течение 28 суток крысам не вызывало достоверных различий динамики массы тела, показателей функционального состояния ЦНС, сердца, мочевыделительной и гепатобилиарной систем, общих анализов крови и мочи. Также показано, что многократное введение атристамина не влияло на массовые коэффициенты внутренних органов, не изменяло их макроскопическое состояние и гистоструктуру.

Таким образом, результаты исследования острой и подострой токсичности атристамина на крысах позволяют сделать вывод о низкой токсичности исследуемого вещества и безопасности при его длительном (28 суток) внутрижелудочном введении в условно терапевтической дозе.

Ключевые слова: атристамин, 2-метил-3-(фениламинометил)-1Н-хинолин-4-он, острая токсичность, подострая токсичность

\section{M. Podolsky, D. V. Lytkin, S. Yu. Shtrygol' \\ The study of the acute and subacute toxicity of the promising antidepressant atristamine in rats}

The side effects of antidepressants, especially under long-term use, are often the decisive factors that hinder the successful treatment of depressive disorders. In the process of developing and introducing innovative antidepressant drugs into medical practice, special attention must be paid to the safety parameters of the studied substances, taking into account the duration of the treatment courses in the clinic.

The aim of the work was to study the acute and subacute toxicity of the promising antidepressant with an original spectrum of additional neurotropic effects 2-methyl-3-(phenylaminomethyl)-1H-quinolin-4one (atristamine) in rats.

The parameters of acute toxicity have been studied on white outbred male rats with single intragastric introduction of atristamine by the method of Prozorovskiy. The study of the subacute toxicity has been performed on 3-4-month-old nonlinear white rats of both sexes with repeated intragastric introduction of atristamine for 28 days in a conditionally therapeutic dose of $100 \mathrm{mg} / \mathrm{kg}$. During the experiment, the effect of repeated administration of atristamine on the dynamics of animal body weight, the functional state of the central nervous system, heart, urinoexcretory and hepatobiliary systems, general blood and urine tests, mass coefficients of internal organs, their macroscopic state and histostructure were determined. 
Based on the results of the acute toxicity study of atristamine, the $L_{50}$ value $(4164 \pm 309 \mathrm{mg} / \mathrm{kg})$ for a single intragastric introduction in rats has been calculated. It allows us to attribute atristamine to class IV (low toxic) substances according to the Hodge and Sterner classification.

The results of the subacute toxicity study demonstrate that daily intragastric introduction of atristamine in rats at a conditionally therapeutic dose for 28 days did not cause significant differences in the dynamics of body weight, indicators of the functional state of the central nervous system, heart, urinoexcretory and hepatobiliary systems, general blood and urine tests. It was also shown that repeated introduction of atristamine did not affect the mass coefficients of internal organs, did not change their macroscopic state and histostructure.

Thus, the results obtained allow us to conclude that the test substance is low toxic and safe with its repeated (28 days) intragastric administation in a conditionally therapeutic dose.

Key words: 2-methyl-3-(phenylaminomethyl)-1H-quinolin-4-one, atristamine, acute toxicity, subacute toxicity

Надійшла: 12 грудня 2019 р.

Прийнята до друку: 12 лютого 2020 р.

Контактна особа: Подольський Ілля Миколайович, кандидат фармацевтичних наук, доцент, кафедра медичної хімії, Національний фармацевтичний університет МОЗУ, буд. 4, вул. Валентинівська, м. Харків, 61168.Тел.: + 380572679204. 